THE KURUME MEDICAL JOURNAL

Vol. 26, No.4, p. 363-369, 1979

\title{
QUENCHING EFFECTS OF VARIOUS COMPOUNDS ON FLUOROMETRIC ASSAY OF TRYPTOPHAN
}

\author{
YASUKO KOHNO, KUMIKO MATSUO, SHIGEKO TAKEDA, \\ MASATOSHI TANAKA AND NOBUYUKI NAGASAKI \\ Department of Pharmacology, Kurume University School of Medicine, \\ Kurume, 830, Japan
}

Received for publication August 25, 1979

\begin{abstract}
Quenching effects of 26 kinds of compounds on the fluorometric assay of tryptophan were studied. Investigated compounds were monoamines, their precursors and metabolites, and drugs used in the study of monoamines. The fluorescence of $1 \mu \mathrm{g}$ of tryptophan was decreased in the presence of the same amount of L-DOPA, catecholamines, DOPAC, 5-HTP, 5 -HT, MK 486 or Ro 4-4602 when these samples were prepared in $0.1 \mathrm{M}$ phosphate buffer ( $\mathrm{pH}$ 7.4) and estimated by the method of Denckla and Dewey. The degree of quenching was varied according to the diluent of the compounds and tryptophan. These results suggest that the direct application of the ultrafiltrate for the assay of free tryptophan might be quenched after administration of drugs. The decreased fluorescence of tryptophan by above compounds, except 5-HTP, was recovered after introducing separation procedure of tryptophan by the Dowex column.
\end{abstract}

\section{INTRODUCTION}

The synthesis of serotonin (5-hydroxytryptamine, 5-HT) in the central nervous system is regulated not only by the activity of the rate-limitting enzyme, tryptophan hydroxylase, but also by the concentration of tryptophan, since the enzyme is normally unsaturated with its substrate (Eccleston et al., 1965 ; Green and Sawyer, 1966 ; Moir and Eccleston, 1968 ; Jequier et al., 1969 ; Tagliamonte et al., 1971; Curzon et al., 1972). The brain concentration of tryptophan depends on the plasma level of the aminoacid and on its transport rate into the brain (Eccleston et al., 1965 ; Oldendorf, 1971 ; Fernstrom and Wurtman, 1972).

In recent years, the significance of plasma levels of free and total(free + albumin bound) tryptophan on the cere- bral metabolism of 5 -HT has been investigated (Fernstrom and Wurtman, 1971 ; Knott and Curzon, 1972 ; Tagliamonte et al., 1973; Curzon and Knott, 1974 ; Brase and Loh, 1975; Wurtman and Fernstrom, 1976 ; Gál et al., 1978). Tryptophan in the plasma is most often determined by the fluorometric method of Denckla and Dewey (1967). The method is based on formation of the fluorophore, norharman, from tryptophan by condensation with formaldehyde and then oxidation with ferric chloride in the acid solution at $100^{\circ} \mathrm{C}$ for $1 \mathrm{hr}$. Usually, this reaction has been applied directly for an assay of tryptophan, i.e., free tryptophan in the ultrafiltrate of plasma and total tryptophan in the deproteinized plasma after the treatment with trichloloacetic acid or perchloric acid(PCA) (Fernstrom and Wurtman, 1971 ; Curzon et 
al., 1972 ; Knott and Curzon, 1972 ; Eccleston, 1973 ; Tagliamonte et al., 1973 ; Mason et al., 1978). However, the direct application means that tryptophan is assayed in crude, only deproteinized extract from plasma, thus the assay, especially that of free tryptophan, might be quenched by such compounds in the plasma as produced after various treatments. Present study was undertaken to investigate how the fluorescence intensity of tryptophan was influenced by presence of various compounds, monoamines, their precursors and metabolites, and drugs generally used in the study of monoamines.

\section{MATERIALS AND METHODS}

Standard solution of tryptophan. Ltryptophan (WAKO PURE CHEMICAL INDUSTRIES, LTD.) was prepared at a concentration of $100 \mu \mathrm{g} / \mathrm{ml}$ in $0.1 \mathrm{~N}$ $\mathrm{NH}_{4} \mathrm{OH}$ and stored in a refregerator up to a month.

Tested compounds. L-phenylalanine, L-tyrosine, histamine, tyramine hydrochloride (WAKO PURE CHEMICAL INDUSTRIES, LTD.), L- $\beta$ - (3,4-dihydroxyphenyl)alanine(L-DOPA), L-adrenaline bitartrate, 4-hydroxy-3-methoxyphenylacetic acid(HVA), 3,4-dihydroxymandelic acid(DOMA), DL-4-hydroxy3-methoxymandelic acid(VMA) (TOKYO CHEMICAL INDUSTRY CO. LTD.), dopamine hydrochloride, serotonin creatinine sulfate(5-HT), 5-hydroxyindole-3acetic acid(5-HIAA), pargyline hydrochloride, DL-p-chlorophenylalanine (PCPA) (NAKARAI CHEMICALS LTD.), L-norepinephrine bitartrate (noradrenaline), 3,4-dihydroxyphenylacetic acid (DOPAC), DL-normetanephrine-hydrochloride, DL-metanephrine hydrochloride, bis (4-hydroxy-3-methoxyphenyl- glycol) piperazine salt (MHPG), kynuramine dihydrobromide, 6-hydroxydopamine hydrobromide(6-OHDA), DL- $\alpha$ methyl-p-tyrosine ( $\alpha$-MT) (SIGMA), L5-hydroxytryptophan (5-HTP) (KYOWA HAKKO CO LTD.), probenecid, carbidopa (MK 486) (NIPPON MERCK-BANYU), and benzerazide hydrochloride (Ro 4-4602) (NIPPON ROCHE K.K.). The samples containing these compounds were prepared daily.

The estimation of tryptophan. All compounds, except probenecid, were dissolved originally in $0.4 \mathrm{~N} \mathrm{PCA}$ at a concentration of $1 \mathrm{mg} / \mathrm{ml}$ as a free base, and then diluted with $0.4 \mathrm{~N}$ PCA, $0.1 \mathrm{M} \mathrm{Na}_{2} \mathrm{HPO}_{4}-\mathrm{KH}_{2} \mathrm{PO}_{4}$ buffer (pH 7.4) or $0.2 \mathrm{~N} \mathrm{CH}_{3} \mathrm{COONa}$. Probenecid was dissolved in $0.1 \mathrm{~N} \mathrm{NaOH}$ and treated in the same way as the others. Standard solution of tryptophan was diluted daily with $0.4 \mathrm{~N}$ PCA, $0.1 \mathrm{M}$ phosphate buffer or $0.2 \mathrm{~N} \mathrm{CH}_{3} \mathrm{COONa}$ at a concentration of $1 \mu \mathrm{g} / 4 \mathrm{ml}$ of tryptophan alone or of tryptophan mixed with increasing amounts $(1,10$, $50 \mu \mathrm{g}$ ) of various compounds dissolved in respective solutions. These samples were estimated by the method of Denckla and Dewey (1967) with a slight modification (Bloxam and Warren,1974) as follows. The samples dissolved in $0.1 \mathrm{M}$ phosphate buffer and $0.2 \mathrm{~N} \mathrm{CH}_{3}$ COONa were acidified by $0.2 \mathrm{ml}$ of 36 $\% \mathrm{HCl}$. To all samples in the three diluents, $0.15 \mathrm{ml}$ of $18 \% \mathrm{HCHO}$ and 0.15 $\mathrm{ml}$ of $0.01 \mathrm{M} \mathrm{FeCl}_{3}$ dissolved in $0.1 \mathrm{~N}$ $\mathrm{HCl}$ were added, or only $0.15 \mathrm{ml}$ of 0.01 $\mathrm{M} \mathrm{FeCl}_{3}$ to the samples for a blank, and the tubes containing the mixtures were firmly stoppered, heated in a boiling water bath for $1 \mathrm{hr}$, and brought to room temperature in running tap water. The fluorescence intensity was read at excitation and emission of $373 \mathrm{~nm}$ and $454 \mathrm{~nm}$, respectively, using 
a fluorescence spectrophotometer(HITACHI MPF-4). The values obtained by subtraction of each blank value were indicated as the percentage of the fluorescence of $1 \mu \mathrm{g}$ of tryptophan.

\section{Separation of tryptophan through} Dowex column. Tryptophan mixed with quenching substances was isolated through the Dowex column, and its fluorescence was measured by the same estimation method. For a preparation of the column, Dowex AG 50W $\times 4$ (200/ 400 mesh, $\mathrm{H}^{+}$form) (BIO•RAD Laboratories) suspended in distilled water was adjusted to $\mathrm{pH} 6.5$ by $5 \mathrm{~N} \mathrm{NaOH}$, then bufferized with $0.1 \mathrm{M} \mathrm{KH}_{2} \mathrm{PO}_{4}-\mathrm{K}_{2} \mathrm{HPO}_{4}$ buffer ( $\mathrm{pH}$ 6.5) and filled to a column (diamiter $0.6 \mathrm{~cm}$, height $3 \mathrm{~cm}$ ). The increasing amounts $(1,10,50 \mu \mathrm{g})$ of various compounds were mixed with 1 $\mu \mathrm{g}$ of tryptophan in $4 \mathrm{ml}$ of $0.4 \mathrm{~N} \mathrm{PCA}$, adjusted to $\mathrm{pH} 2.0-2.5$ with $1 \mathrm{~N} \mathrm{NaOH}$, and passed through the column. After the column was washed with $4 \mathrm{ml}$ of distilled water and $3 \mathrm{ml}$ of $02 \mathrm{~N} \mathrm{CH}_{3}$ $\mathrm{COONa}$, tryptophan was recovered into the following $8 \mathrm{ml}$ of $0.2 \mathrm{~N} \mathrm{CH}_{3} \mathrm{COONa}$. The fluorescence of each sample in $4 \mathrm{ml}$ of the eluate was assayed as described above, and indicated as the percentage of the fluorescence of $1 \mu \mathrm{g}$ of tryptophan.

Assays of free and total tryptophan from the rat plasma. Male Wistar rats weighing $250-300 \mathrm{~g}$ were decapitated, and the blood collected from the body trunk into a heparinized tube was centrifuged at $3000 \mathrm{rpm}$ for $20 \mathrm{~min}$ at $20^{\circ} \mathrm{C}$. The plasma was stored at $-45^{\circ} \mathrm{C}$ untill assayed. The separation of free tryptophan in $1.25 \mathrm{ml}$ of plasma was performed using the ultrafiltration cell with PM 10 membrane (AMICON, model 12) at room temperature. For the direct estimation of tryptophan, $3.5 \mathrm{ml}$ of $0.4 \mathrm{~N} \mathrm{PCA}$ was added to $0.5 \mathrm{ml}$ of the ultrafiltrate, and the free tryptophan was assayed by the same estimation method. Total tryptophan was assayed using $4 \mathrm{ml}$ of the supernate obtained after addition of $5 \mathrm{ml}$ of 0.4 $\mathrm{N} P C A$ to $0.2 \mathrm{ml}$ of the plasma and centrifugation at $12000 \mathrm{rpm}$ for $10 \mathrm{~min}$ in the cold. For the column separation of free and total plasma tryptophan, $0.5 \mathrm{ml}$ of the ultrafiltrate or $4 \mathrm{ml}$ of the PCA extract from the plasma was adjusted to $\mathrm{pH} 2.0-2.5$ with $0.1 \mathrm{~N} \mathrm{HCl}$ or with $1 \mathrm{~N} \mathrm{NaOH}$, respectively, and passed through the column as described above.

\section{RESULTS}

Quenching effects of 26 kinds of compounds diluted in $0.4 \mathrm{~N}$ PCA on the estimation of tryptophan are shown in Table 1. When $1 \mu \mathrm{g}$ of tryptophan was mixed with the same amount of the compounds in $0.4 \mathrm{~N} \mathrm{PCA}$, the fluorescence of tryptophan was slightly affected. However, the marked decrease of the fluorescence was found in the presence of the tenfold amounts of such compounds as catecholamines, 5HT, their precursors (L-DOPA, 5-HTP) and metabolites(HVA, DOPAC, DOMA, MHPG, 5-HIAA), and related compounds(6-OHDA, Ro 4-4602). Phenylalanine, histamine, tyramine, pargyline, PCPA and $\alpha$-MT did not decrease the fluorescence even in the presence of the compounds of which concentrations were 50 times amount of tryptophan.

The quenching effects of 14 kinds of compounds dissolved in $0.1 \mathrm{M}$ phosphate buffer $\left(\mathrm{pH} \mathrm{7.4)}\right.$ and $0.2 \mathrm{~N} \mathrm{CH}_{3}$ $\mathrm{COONa}$ were compared with those in $0.4 \mathrm{~N}$ PCA. Among the three diluents, the tested compounds tended to de- 
crease the fluorescence of tryptophan most potently when they were dissolved in $0.1 \mathrm{M}$ phosphate buffer, and more

\section{TABLE 1}

Effects of various compounds on the fluorescence intensity of tryptophan

\begin{tabular}{|c|c|c|c|}
\hline \multirow{3}{*}{ compounds } & \multirow{2}{*}{\multicolumn{3}{|c|}{$\begin{array}{l}\text { fluorescence intensities } \\
\text { (\%) } \\
\text { amounts of compounds } \\
\text { mixed with } 1 \mu \mathrm{g} \text { of } \\
\text { tryptophan }\end{array}$}} \\
\hline & & & \\
\hline & $1 \mu \mathrm{g}$ & $10 \mu \mathrm{g}$ & $50 \mu \mathrm{g}$ \\
\hline phenylalanine & 102 & 99 & 100 \\
\hline tyrosine & 101 & 89 & 70 \\
\hline L-DOPA & 92 & 38 & 0 \\
\hline dopamine & 96 & 38 & 0 \\
\hline noradrenaline & 94 & 44 & 1 \\
\hline adrenaline & 96 & 44 & 1 \\
\hline HVA & 97 & 71 & 18 \\
\hline DOPAC & 99 & 47 & 4 \\
\hline DOMA & 100 & 62 & 5 \\
\hline normetanephrine & 96 & 83 & 44 \\
\hline metanephrine & 96 & 83 & 50 \\
\hline VMA & 106 & 94 & 76 \\
\hline MHPG & 96 & 53 & 9 \\
\hline 5-HTP & 102 & 79 & 0 \\
\hline 5-HT & 105 & 73 & 4 \\
\hline 5-HIAA & 106 & 74 & 8 \\
\hline kynuramine & 109 & 103 & 83 \\
\hline histamine & 103 & 98 & 98 \\
\hline pargyline & 103 & 94 & 94 \\
\hline probenecid & 110 & 105 & 81 \\
\hline tyramine & 103 & 106 & 105 \\
\hline PCPA & 101 & 104 & 95 \\
\hline 6-OHDA & 94 & 46 & 0 \\
\hline$\alpha$-MT & 103 & 102 & 95 \\
\hline MK 486 & 104 & 94 & 70 \\
\hline Ro 4-4602 & 94 & 75 & 13 \\
\hline
\end{tabular}

Tryptophan and above compounds were dissolved in $0.4 \mathrm{~N} \mathrm{PCA}$, and the estimation procedure for tryptophan was carried out. Fluorescence intencities are indicated as the percentage of fluorescence of $1 \mu \mathrm{g}$ of tryptophan after being corrected by each blank value. Values are indicated as the mean of duplicate samples. potently in $0.2 \mathrm{~N} \mathrm{CH}_{3} \mathrm{COONa}$ than in $0.4 \mathrm{~N}$ PCA (See Tables 1 and 2). Being diluted in $0.1 \mathrm{M}$ phosphate buffer, even $1 \mu \mathrm{g}$ of L-DOPA, catecholamines, DOPAC and Ro 4-4602 reduced the fluorescence of $1 \mu \mathrm{g}$ of tryptophan to less than $80 \%$.

In successive experiment, we examined whether the quenching of the compounds, the values of which were less than $90 \%$ in the presence of $10 \mu \mathrm{g}$ of these compounds in the Table 1 , can be abolished by introducing the separation procedure with the Dowex column.

TABLE 2

Effects of various compounds in the different diluents on fluorescence intensity of tryptophan

\begin{tabular}{|c|c|c|c|c|}
\hline \multirow{4}{*}{ compounds } & \multicolumn{4}{|c|}{ diluents } \\
\hline & \multicolumn{2}{|c|}{$\begin{array}{l}0.1 \mathrm{M} \text { phosphate } \\
\text { buffer (pH 7.4) }\end{array}$} & \multicolumn{2}{|c|}{$\begin{array}{c}0.2 \mathrm{~N} \\
\mathrm{CH}_{3} \mathrm{COONa}\end{array}$} \\
\hline & \multicolumn{4}{|c|}{$\begin{array}{l}\text { amounts of compounds mixed } \\
\text { with } 1 \mu \mathrm{g} \text { of tryptophan }\end{array}$} \\
\hline & $1 \mu \mathrm{g}$ & $10 \mu \mathrm{g}$ & $1 \mu \mathrm{g}$ & $10 \mu \mathrm{g}$ \\
\hline L-DOPA & 78 & 17 & 84 & 16 \\
\hline dopamine & 74 & 15 & 83 & 14 \\
\hline noradrenaline & 71 & 17 & 82 & 19 \\
\hline adrenaline & 78 & 15 & 81 & 21 \\
\hline DOPAC & 79 & 19 & 83 & 19 \\
\hline HVA & 111 & 61 & 95 & 49 \\
\hline 5-HTP & 86 & 29 & 88 & 31 \\
\hline 5-HT & 89 & 27 & 84 & 30 \\
\hline 5-HIAA & 92 & 29 & 90 & 30 \\
\hline$\alpha-\mathrm{MT}$ & 102 & 102 & 105 & 104 \\
\hline MK 486 & 80 & 44 & 101 & 58 \\
\hline Ro 4-4602 & 71 & 39 & 95 & 47 \\
\hline probenecid & 98 & 103 & 100 & 100 \\
\hline pargyline & 99 & 103 & 101 & 99 \\
\hline
\end{tabular}

Tryptophan and above compounds were diluted with $0.1 \mathrm{M}$ phosphate buffer ( $\mathrm{pH} 7.4$ ) or $0.2 \mathrm{~N} \mathrm{CH}_{3} \mathrm{COONa}$, and the estimation procedure for tryptophan was carried out. Further explanations are in the legend of Table 1 . 
TABLE 3

Effects of various compounds on the assay of tryptophan through the column separation

\begin{tabular}{|c|c|c|c|}
\hline \multirow{3}{*}{ compounds } & \multirow{2}{*}{\multicolumn{3}{|c|}{$\begin{array}{c}\text { fluorescence intensities } \\
(\%) \\
\text { amounts of compounds } \\
\text { mixed with } 1 \mu \mathrm{g} \text { of } \\
\text { tryptophan }\end{array}$}} \\
\hline & & & \\
\hline & $1 \mu \mathrm{g}$ & $10 \mu \mathrm{g}$ & $50 \mu \mathrm{g}$ \\
\hline tyrosine & 100 & 105 & 106 \\
\hline L-DOPA & 102 & 102 & 99 \\
\hline dopamine & 103 & 102 & 92 \\
\hline noradrenaline & 105 & 109 & 111 \\
\hline adrenaline & 106 & 111 & 116 \\
\hline HVA & 97 & 111 & 116 \\
\hline DOPAC & 100 & 107 & 100 \\
\hline DOMA & 100 & 107 & 116 \\
\hline normetanephrine & 104 & 100 & 104 \\
\hline metanephrine & 100 & 100 & 104 \\
\hline MHPG & 101 & 103 & 107 \\
\hline 5-HTP & 106 & 89 & 57 \\
\hline 5-HT & 103 & 111 & 109 \\
\hline 5-HIAA & 104 & 109 & 113 \\
\hline 6-OHDA & 106 & 107 & 101 \\
\hline MK 486 & 110 & 113 & 116 \\
\hline Ro 4-4602 & 103 & 103 & 106 \\
\hline
\end{tabular}

Tryptophan mixed with above compounds was isolated through the Dowex column as described in the text, and estimated for tryptophan. Further explanations are in the legend of Table 1 .

As shown in Table 3, decreasing effects on the fluorescence of tryptophan were diminished after the column separation in most compounds, however, the large amount of 5-HTP still showed the effect.

The values of free and total tryptophan in the rat plasma both with the direct estimation and with the estimation after the column separation are indicated in Table 4 . The values obtained from normal plasma were much alike between the two methods, how-
TABLE 4

Concentrations of free and total tryptophan in the rat plasma

\begin{tabular}{|c|c|c|}
\hline & $\begin{array}{l}\text { tryptophan } \\
\text { free } \\
(\mu \mathrm{g} / \mathrm{ml})\end{array}$ & $\begin{array}{l}\text { concentra- } \\
\text { tions } \\
\text { total } \\
(\mu \mathrm{g} / \mathrm{ml})\end{array}$ \\
\hline \multicolumn{3}{|l|}{ direct estimation } \\
\hline normal rat & $2.07 \pm 0.11$ & $22.50 \pm 0.97$ \\
\hline$\underset{\text { rat }^{1)}}{\text { L-DOPA-treated }}$ & $0.82 \pm 0.09$ & $15.75 \pm 0.77$ \\
\hline \multicolumn{3}{|c|}{$\begin{array}{c}\text { estimation after column } \\
\text { separation }{ }^{2}\end{array}$} \\
\hline normal rat & $1.95 \pm 0.19$ & $21.81 \pm 1.03$ \\
\hline $\begin{array}{l}\text { L-DOPA-treated } \\
\text { rat }^{1)}\end{array}$ & $3.44 \pm 0.26$ & $17.40 \pm 0.65$ \\
\hline
\end{tabular}

Each value represents the mean \pm SEM of 6-7 determinations. 1); the rats were decapitated at $60 \mathrm{~min}$ after an i. p. injection of L-DOPA, $200 \mathrm{mg} / \mathrm{kg}$. 2) ; the ultrafiltrates or the $0.4 \mathrm{~N}$ PCA extracts of the plasma were shaken with activated alumina at $\mathrm{pH}$ 7.5-8.0, and the supernatants were adjusted to $\mathrm{pH} 2.0-2.5$ with $1 \mathrm{~N} \mathrm{HCl}$ and applied to the column, and treated as described in the text.

ever, those obtained from the L-DOPAtreated rat showed large discrepancy depending on the methods.

\section{DISCUSSION}

Hess and Udenfriend (1969) devised originally the formation of norharman, which was highly specific to only tryptophan or tryptamine, and Denckla and Dewey (1967) addapted the reaction to determine tryptophan in the plasma or in the other tissues. However, the assay was reported to be quenched by certain metal ions (Denckla and Dowey, 1967), L-DOPA (Curzon and Knott, 1974) or sucrose and other keto sugars (Woodcock and Khairallah, 1976) and also by a light (Lehman, 1971). In the present study, quenching effects of 26 kinds of compounds on the assay 
was studied. The standard amount of tryptophan, $1 \mu \mathrm{g}$, is equivalent to the amount of free tryptophan in $0.5 \mathrm{ml}$ of the ultrafiltrate of the rat plasma. As shown in Tables 1 and 2, the fluorescence of tryptophan was decreased markedly by many compounds according to their increasing amounts, and potentiated slightly by a few compounds. Although the chemical explanations of these phenomenon were not defind, further addition of $\mathrm{HCHO}$ or $\mathrm{FeCl}_{3}$ could not recover the quenching effects and moreover decreased the fluorescence of tryptophan itself.

The degree of the quenching was changed according to the kind of diluents of the compounds. L-DOPA, catecholamines, DOPAC, 5-HTP, 5-HT, 5HIAA and Ro 4-4602 showed more marked reduction of the fluorescence of tryptophan when dissolved in somewhat alkaline solution than in $0.4 \mathrm{~N} \mathrm{PCA}$ as shown in Tables 1 and 2. These findings suggest the possibility that not only the compounds themselves, but also their degradated compounds decreased the fluorescence of tryptophan.

When tryptophan was separated by the column, the mean recovery of the aminoacid was $93 \%$, and none of the compounds tested, except 5-HTP, decreased the fluorescence of tryptophan. On the contrary, some of the catecholamines, HVA, DOPAC, DOMA, 5-HT, 5-HIAA and MK 486 increased slightly the fluorescence of tryptophan. When tryptophan mixed with L-DOPA, catecholamines, DOPAC or MK 486 was shaken with activated alumina under $\mathrm{pH} 7.5-8.0$, then adjusted to $\mathrm{pH} 2.0-$ 2.5 with $1 \mathrm{~N} \mathrm{HCl}$ and passed through the column, the quenching effect of the compounds could be removed completely.

Even after the column separation, it should be needed to examine the existence of quenching effects. We observed that not only tryptophan but also these quenching compounds, LDOPA, dopamine, 5-HTP, 5-HT and MK 486, were eluted in more concentrated way than with $0.2 \mathrm{~N} \mathrm{CH}_{3} \mathrm{COONa}$ when the aminoacid retained by the resin was eluted with $0.1-0.5 \mathrm{~N} \mathrm{NH}_{4} \mathrm{OH}$ proposed by Korobath et al. (1971).

Although the quenching effects of various compounds were studied in vitro, the results suggest that the effects are likely to occur in the assay of tryptophan in tissue samples if the estimation method is applied directly to their deproteinized extracts. Actually, the changes of plasma tryptophan in the L-DOPA-treated rat were different according to the assay methods, and the difference was more remarkable in the results of free tryptophan than in those of total tryptophan (See in Table 4).

The assay of plasma tryptophan by the direct method might not be interfered with the endogenous substances under physiological condition in which their concentrations were not so high (See in Table 4).

The method of Denckla and Dewey is simple and sensitive, and has been generally adopted in determination of plasma tryptophan by manually operated and autoanalyzed methods. However, our results serve a notice to the direct application after administration of drugs, especially to the application for the assay of free tryptophan, which controls brain tryptophan level and 5HT synthesis (Knott and Curzon, 1972 ; Tagliamonte et al., 1973). For the accurate assay of tryptophan in the tissue samples, the estimation method should be applied after introducing appropriate separation procedure for tryptophan to remove quenching compounds. 


\section{REFERENCES}

Bloxam, D. L. and WARren, W. H. (1974). Error in the determination of tryptophan by the method of Denckla and Dewey. A revised procedure. Anal. Biochem., 60, 621625.

Brase, D. A. and LoH, H. H. (1975). Possible role of 5-hydroxytryptamine in minimal brain dysfunction. Life Sci, 16, 1005-1016.

Curzon, G, Joseph, M. H. and Knott, P. J. (1972). Effects of immobilization and food deprivation on rat brain tryptophan metabolism. J. Neurochem., 19, 1967-1974.

Curzon, G. and KnotT, P. J. (1974). Effects on plasma and brain tryptophan in the rat of drugs and hormones that influence the concentration of unesterified fatty acid in the plasma. Br. J. Pharmac., 50, 197-204.

Denckla, W.D. and Dewey, H.K. (1967). The determination of tryptophan in plasma, liver, and urine. J. Lab. Clin. Med., 69, 160-169.

Eccleston, D., Ashcroft, G. W. and Crawford, T.B.B. (1965). 5-Hydroxyindole metabolism in rat brain. A study of intermediate metabolism using the technique of tryptophan loading-II. Applications and drug studies. J. Neurochem, 12, 493-503.

Eccleston, E. G. (1973). A method for the estimation of free and total acid-soluble plasma tryptophan using an ultrafiltration technique. Clin. Chim. Acta, 48, 269-272.

Fernstrom, J.D. and Wurtman, R. J. (1971). Brain serotonin content: Increase following ingestion of carbohydrate diet. Science, 174, $1023-1025$.

Fernstrom, J.D. and Wurtman, R. J. (1972). Brain serotonin content: Physiological regulation by plasma neutral amino acids. Science, 178, 414-416.

Gaitonde, M. K, Evans, G. and Hartmann, M. K. (1979). Determination of tryptophan by manually operated and autoanalyzer methods based on the formation of norharman. Anal. Biochem, 92, 338-344.

Gál, E.M. Young, R.B. and Sherman, A.D. (1978). Tryptophan loading : consequent effects on the synthesis of kynurenine and 5 -hydroxyindoles in rat brain. J. Neurochem, 31, 237-244.

Green, H. and SAwyer, J. L. (1966). Demonstration, characterization and assay pro- cedure of tryptophan hydroxylase in rat brain. Anal. Biochem, 15, 53-57.

HESS, S. M. and Udenfriend, S. (1959). A fluorometric procedure for the measurement of tryptamine in tissues. J. Pharmacol. Exp. Ther., 127, 175-177.

JEQUIER, E., ROBINSON, D. S., LOVENBERG, W. and Sjoerdsma, A. (1969). Further studies on tryptophan hydroxylase in rat brain stem and beef pineal. Biochem. Pharmacol, 18, 1071-1081.

Karobath, M. Díaz, J-L. and Huttunen, M.O. (1971). The effect of L-dopa on the concentrations of tryptophan, tyrosine and serotonin in rat brain. European J. Pharmacol, 14, 393-396.

Knott, P. J. and Curzon, G. (1972). Free tryptophan in plasma and brain tryptophan metabolism. Nature (London), 239, 452-453.

Lehmann, J. (1971). Light - a source of error in the fluorometric determination of tryptophan. Scand. J. Clin. Lab. Invest., 28, 49-55.

Mason, G. A., Diez, J. A., Dutton, H. H. and Summer, G. K. (1978). Automated fluorometric determination of free and total tryptophan in plasma. Anal. Biochem, 84, 231-239.

Moir, A.T.B. and Eccleston, D. (1968). The effects of precursor loading in the cerebral metabolism of 5-hydroxyindoles. $\mathrm{J}$. Neurochem., 15, 1093-1108.

OlDENDORF, W. H. (1971). Brain uptake of radiolabelled amino acids, amines, and hexoses after arterial injection. Amer. J. Physiol, 221, 1629-1639.

Tagliamonte, A. Tagliamonte, P., PerezCruet, J., Stern, S. and Gessa, G.L. (1971). Effect of psychotropic drugs on tryptophan concentration in the rat brain. J. Pharmacol, 177, 475-480.

Tagliamonte, A., Biggio, G., Vargiu, L. and Gessa, G. L. (1973). Free tryptophan in serum controls brain tryptophan level and serotonin synthesis. Life Sci. Part II, 12, 277-287.

Woodcock, J.L. and KHAirallah, E. A. (1976). Interference of sucrose with the fluorometric assay of tryptophan. Anal. Biochem., 72, 139-143.

Wurtman, R. and Fernstrom, J. D. (1976). Control of brain neurotransmitter synthesis by precursors availability and nutritional state. Biochem. Pharmacol, 25, 1691-1696. 